\title{
Reinstatement of Aloe candelabrum A.Berger (Asphodelaceae: Alooideae), a tree-like aloe of KwaZulu-Natal province, South Africa
}

\section{Gideon F. Smith ${ }^{1,2}$, Ronell R. Klopper ${ }^{3,4}$, Neil R. Crouch ${ }^{5,6}$ \& Estrela Figueiredo ${ }^{1,2}$}

1. Centre for Functional Ecology, Departamento de Ciências da Vida, Universidade de Coimbra, 3001-455 Coimbra, Portugal.

2. Department of Botany, P.O. Box 77000, Nelson Mandela Metropolitan University, Port Elizabeth, 6031 South Africa (email: smithgideon1@gmail.com; epnfigueiredo@gmail.com).

3. Biosystematics Research and Biodiversity Collections Division, South African National Biodiversity Institute, Private Bag X101, Pretoria, 0001 South Africa (email: R.Klopper@sanbi.org.za).

4. H.G.W.J. Schweickerdt Herbarium, Department of Plant and Soil Sciences, University of Pretoria, Pretoria, 0002 South Africa.

5. Biodiversity Research, Assessment and Monitoring, South African National Biodiversity Institute, P.O. Box 52099, 4007 Berea Road, South Africa (email: N.Crouch@sanbi.org.za).

6. School of Chemistry and Physics, University of KwaZulu-Natal, 4041 Durban, South Africa.

Summary: Aloe candelabrum A.Berger (Asphodelaceae: Alooideae), a stately, single-stemmed species from the KwaZulu-Natal province in eastern South Africa, which had been included in the synonymy of $A$. ferox Mill. for some years, is reinstated. The entire distribution range of $A$. candelabrum falls within the Maputoland-Pondoland Region of Endemism on the eastern seaboard of South Africa. In contrast, Aloe ferox occurs widely in the Western and Eastern Cape provinces of South Africa, the southern Free State province, as well as southern Lesotho. It does not occur in KwaZulu-Natal.

Zusammenfassung: Aloe candelabrum A. Berger (Asphodelaceae: Alooideae), eine stattliche, einstämmige Art aus der Provinz KwaZulu-Natal im östlichen Südafrika, die jahrelang in die Synonymie von $A$. ferox Mill. gestellt wurde, wird wieder anerkannt. Das gesamte Verbreitungsgebiet von A. candelabrum liegt innerhalb der Endemismus-Region Maputoland-Pondoland an der östlichen Meeresküste von Südafrika. Im Gegensatz dazu ist Aloe ferox weit verbreitet in den südafrikanischen Provinzen Western Cape und Eastern Cape, der südlichen Provinz Free State sowie im südlichen Lesotho; in KwaZulu-Natal kommt sie nicht vor.

\section{Introduction}

The work of Reynolds (1950) on Aloe L. in South Africa has proven remarkably robust; the circumscriptions for taxa he recognised have predominantly stood the test of time. Despite the subsequent synonymising of several well-known species and subordinate taxa (by inter alia, Glen \& Hardy, 2000), most of these have recently been reinstated (see for example Smith et al., 2012 on summer-flowering maculate aloes, and Klopper \& Smith, 2010 on Aloe spectabilis Reynolds).

A further such species requiring reinstatement is Aloe candelabrum A.Berger. We here clarify how this species, an apparent endemic of KwaZulu-Natal province in eastern South Africa, differs from Aloe ferox Mill., under which it was subsumed (Viljoen et al., 1996). Following an assessment of the various features invoked as diagnostic by earlier authors to separate these species (Reynolds, 1950; Jeppe, 1969; Bornman \& Hardy, 1971), we conclude that both the name and concept for Aloe candelabrum warrant resurrection, albeit on an amended character set.

Differences between mature specimens of Aloe candelabrum and Aloe ferox

Aloe candelabrum is characterised by its tall [2-4(-8)m high], erect, unbranched stem covered in a 'beard' of persistent, dried leaves, with a terminal rosette of long $(c a .100 \times 15 \mathrm{~cm})$, spreading 


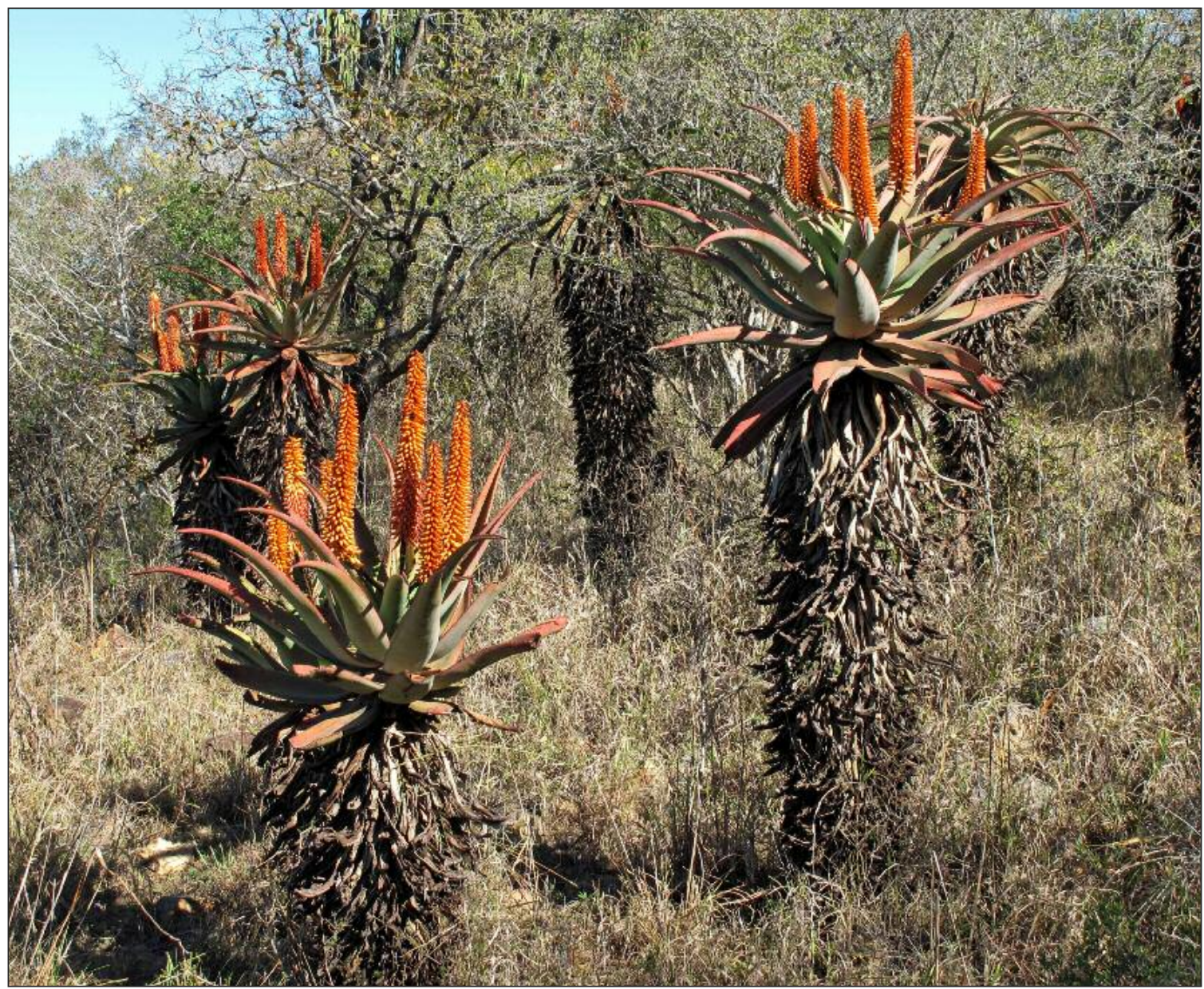

Figure 1. The large rosettes of Aloe candelabrum are carried atop robust stems that are clothed in the remains of dry leaves, Ashburton, KwaZulu-Natal province. Photograph: Neil R. Crouch.

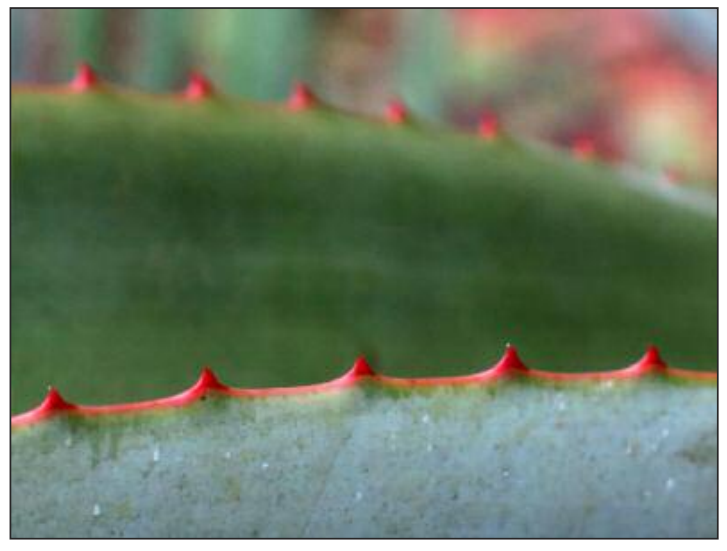

Figure 2. The channelled leaves of Aloe candelabrum have margins armed with reddish-brown teeth.

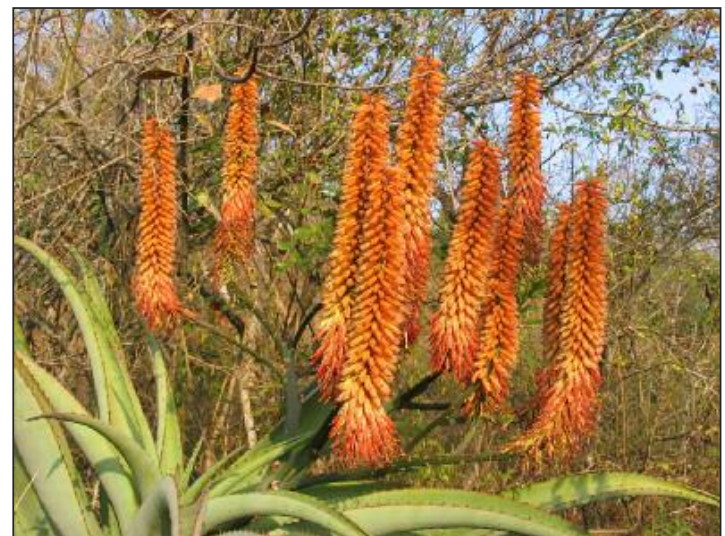

Figure 3. The inflorescences of Aloe candelabrum resemble chandeliers, and have up to 12 raceme branches. Although not obvious in this Ashburton plant, the terminal raceme is often longer than the laterals.

Photograph: Neil R. Crouch. 


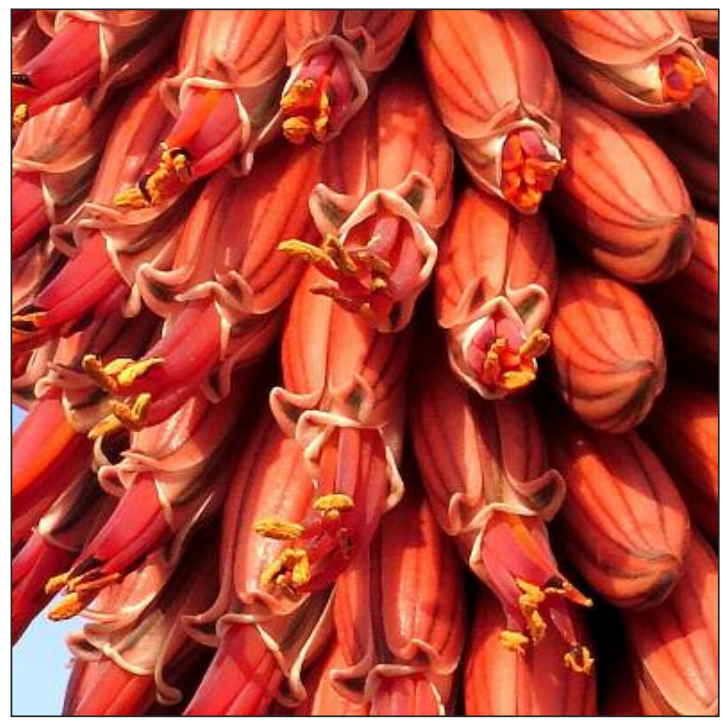

Figure 4. Orange-red flowers of Aloe candelabrum, with prominent white flared tepal apices, Ashburton, KwaZulu-Natal province.

Photograph: Neil R. Crouch.

to often recurved, deeply channelled leaves (Figure 1) that sometimes bear a few scattered spines on the lower surface, especially at the tip of the keel. The reddish to reddish-brown marginal teeth are pungent and $c a .3 \mathrm{~mm}$ long (Figure 2). The candelabrum-like inflorescence is 5 - to 12 branched with erect, very dense, cylindrical, slightly acuminate racemes $50-80 \mathrm{~cm}$ long, with the terminal raceme sometimes slightly longer than the lateral ones (Figures 1 and 3). Flowers are scarlet, sometimes rose-pink, orange-red (Figure 4) to orange (Figure 5), and ca. $32 \mathrm{~mm}$ long, always with white inner segment tips (Figures 4 and 5) (Table 1). Very rarely they are white (Figure 6).

The closest relative of Aloe candelabrum is Aloe ferox, both of which are included in Group 4B of $A$. sect. Pachydendron Haw. (Reynolds, 1950: 442). This has been confirmed by HPLC analyses of leaf exudates that reveal similar profiles for anthrone and chromone derivatives (Viljoen et al., 1996). Aloe ferox is a species very widely distributed in the southern and east-central parts of South Africa, as well as southern Lesotho. It is similarly distinguished by a tall $[2-3(-5) \mathrm{m}]$ erect, unbranched stem with persistent dried leaves and a terminal rosette (Figure 7). The leaves of Aloe ferox are typically erect to erectly spreading (rarely up to $100 \mathrm{~cm}$ ), with marginal teeth of $c a .6 \mathrm{~mm}$ long (Figure 8) and both surfaces either smooth or with irregularly scattered, pungent spines. The lower surface bears a few spines in the median line near

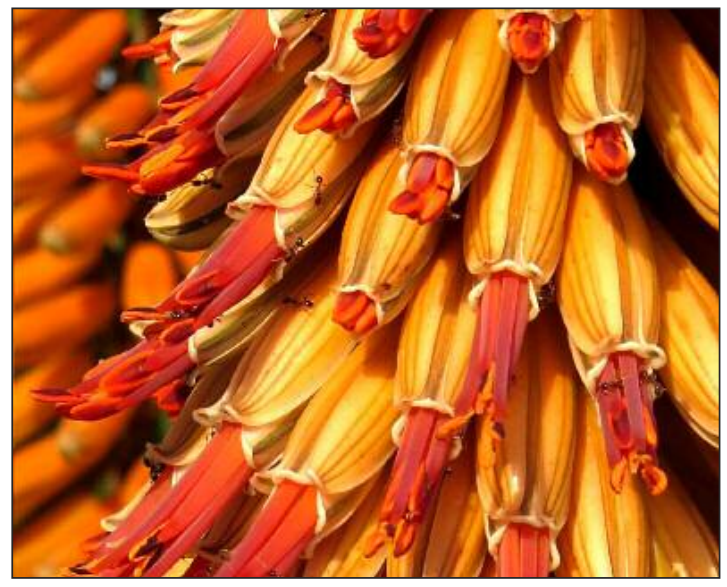

Figure 5. Another Ashburton flower form of Aloe candelabrum is orange, with scarlet and rose-pink forms also present. The flared white inner tepal apices are conspicuous.

Photograph: Neil R. Crouch.

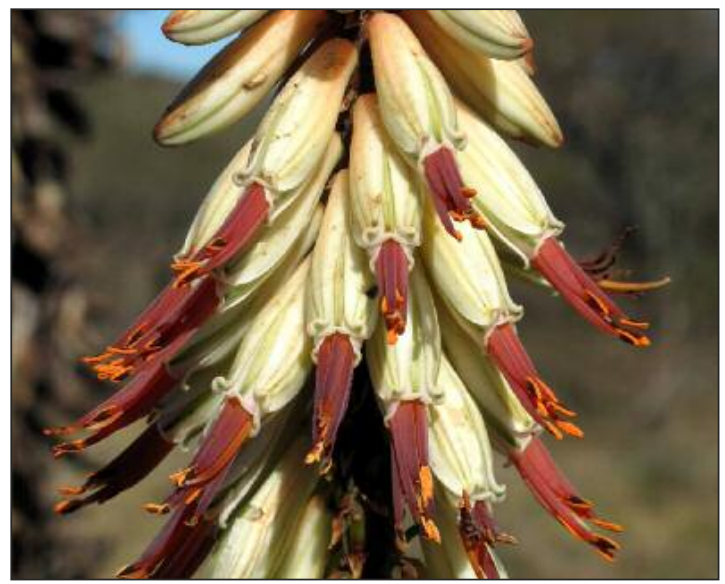

Figure 6. Rare white flowers of Aloe candelabrum, Ashburton, KwaZulu-Natal province.

Photograph: Neil R. Crouch.

the apex (Figure 9). The candelabrum-like inflorescence is 5- to 8-branched (Figure 7), generally with all racemes of approximately equal length, although one may be prominently taller. Flowers are mostly scarlet to orange, rarely white, and $c a$. $33 \mathrm{~mm}$ long with the inner segments tips brown to deep brown (Figures 10 and 11), or at least more intensely coloured than the rest of the corolla. The inner tepal apices typically do not flare (Figures 10 and 11) (Table 1). Whereas the inner segment tips of $A$. candelabrum tepals flare and are the same colour to the margin (in some herbarium specimens the white margins are still clearly evident), in A. ferox the inner tepal tips barely spread and are distinctly dark. It is only in old herbarium 


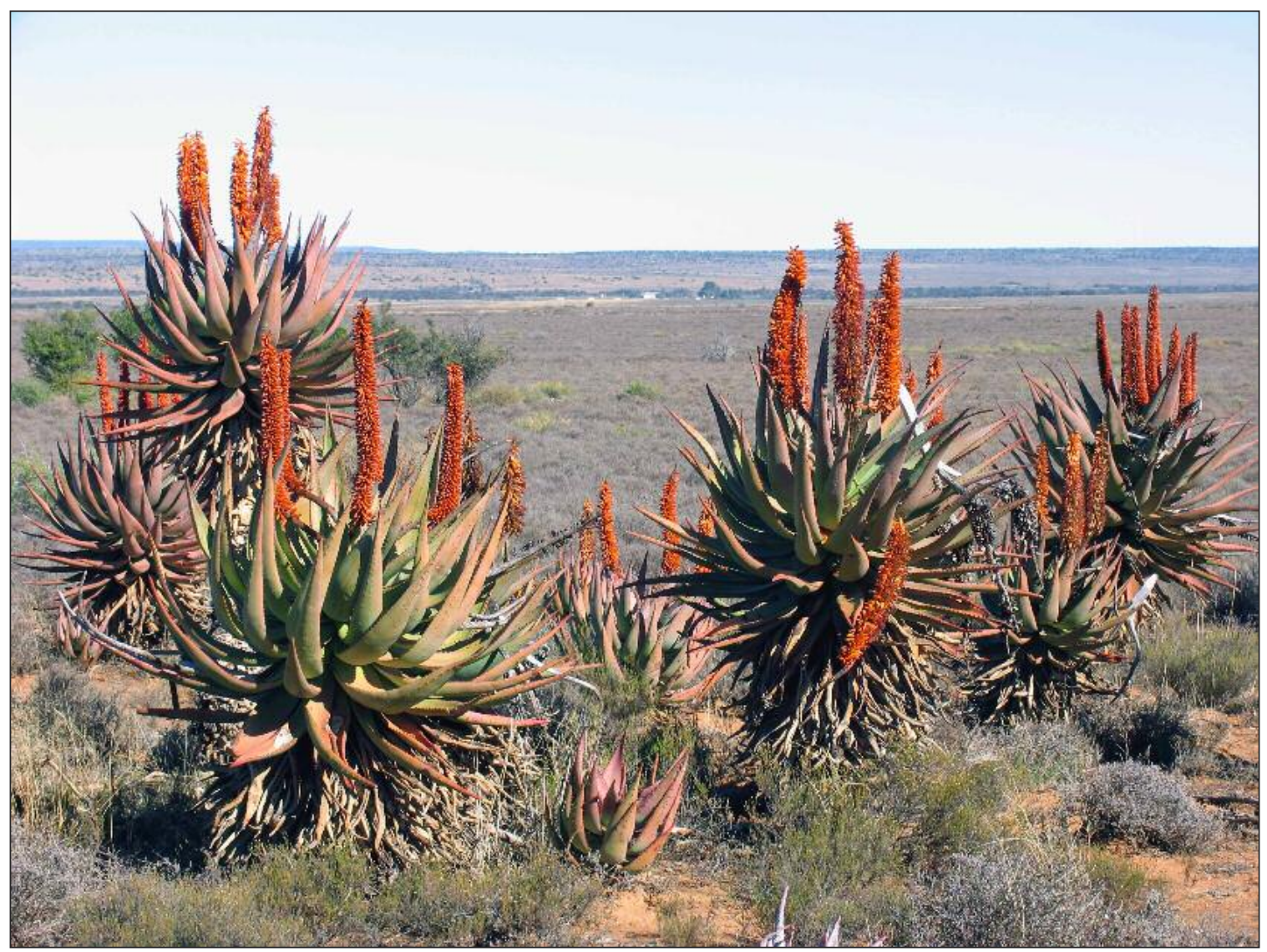

Figure 7. Colony of Aloe ferox plants, Jansenville, Eastern Cape province. Robust stems clothed in persistent, dried leaves present rosettes of erect to spreading leaves, rarely recurved.

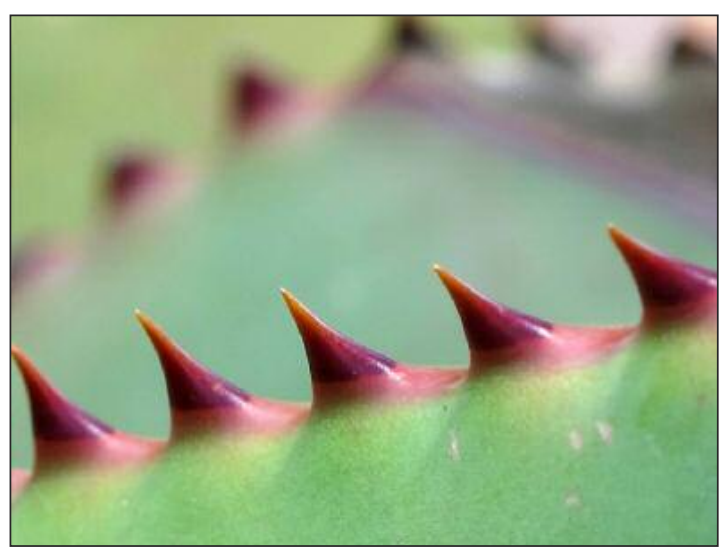

Figure 8. Pungent reddish-brown spines along the leaf margins of Aloe ferox, Nieu Bethesda, Eastern Cape province.

Photograph: Neil R. Crouch.

Photograph: Neil R. Crouch.

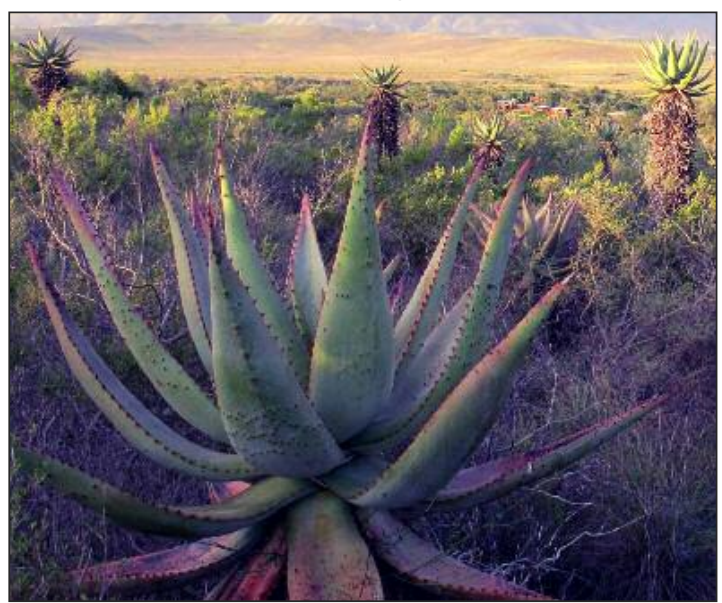

Figure 9. Population of Aloe ferox south of Swellendam, Western Cape province. Both leaf surfaces are either smooth or with irregularly scattered, pungent spines, and the lower surface has a few spines in the median line near the apex. Photograph: Estrela Figueiredo. 
Table 1. Differences between mature specimens of Aloe candelabrum and Aloe ferox.

\begin{tabular}{|c|c|c|c|}
\hline \# & Character & Aloe candelabrum & Aloe ferox \\
\hline 1 & Rosette & Very large (c. $2 \mathrm{~m}$ diam.) & Medium-sized to large ( $<2 \mathrm{~m}$ diam.) \\
\hline 2 & Leaf length & c. $1 \mathrm{~m}$ & $<1 \mathrm{~m}$ rarely to $1 \mathrm{~m}$ \\
\hline 3 & $\begin{array}{l}\text { Leaf curvature / } \\
\text { disposition }\end{array}$ & $\begin{array}{l}\text { Spreading to often gracefully re- } \\
\text { curved, occasionally erect }\end{array}$ & $\begin{array}{c}\text { Erect to somewhat spreading, } \\
\text { seldom recurved }\end{array}$ \\
\hline 4 & $\begin{array}{l}\text { Inflorescence } \\
\text { structure }\end{array}$ & Up to 12 raceme branches & Not more than 8 raceme branches \\
\hline 5 & Tepal apices colour & $\begin{array}{l}\text { Lighter, white-tipped. Outer } \\
\text { slightly darker than inner }\end{array}$ & $\begin{array}{l}\text { Darker, brown-tipped. } \\
\text { Outer always lighter than inner }\end{array}$ \\
\hline 6 & $\begin{array}{l}\text { Inner tepal apices } \\
\text { disposition }\end{array}$ & Flared, filaments free & Not flared, often clasp filaments \\
\hline 7 & Distribution range & $\begin{array}{l}\text { East-central KwaZulu-Natal } \\
\text { province of South Africa }\end{array}$ & $\begin{array}{c}\text { Western Cape, Eastern Cape, } \\
\text { and Free State provinces of } \\
\text { South Africa; Lesotho }\end{array}$ \\
\hline
\end{tabular}

specimens presenting flowers dried very dark (with colour deepening perhaps heightened by pre-treatment with a petroleum product) that this character is indistinct. Reynolds (1950) considered leaf channelling to be more accentuated in $A$. candelabrum; our observations, however, reveal this to be a weakly supported character, as too is the prominence of elevation of the central raceme branch.

In the eastern parts of the Eastern Cape province and southern parts of KwaZulu-Natal, and from the Mtamvuna valley through to Ixopo, Aloe candelabrum and A. ferox seemingly intergrade. This is evidenced by some populations having plants with more erect leaves (Figures 12 and 13) or slightly recurved ones (Figure 14), and $A$. ferox-like spines along both leaf margins and undersides (Figure 15). We speculate that it is on this basis that Jeppe (1969) considered A. ferox to occur from south of Ixopo. However, within this southern KwaZulu-Natal region white perianth apices are always evident, an observation also noted by Viljoen et al. (1996). Where the distribution ranges of related Aloe species meet, such intergradations are not uncommon, as noted for $A$. spectabilis (Klopper \& Smith, 2010).

In Aloe candelabrum the teeth on the leaf margins are quite short and stout, about $3 \mathrm{~mm}$ long, and spaced 15-20mm apart (Figure 2), while in $A$. ferox the teeth are generally larger and more prominent, up $6 \mathrm{~mm}$ long, and often more closely spaced at $10-20 \mathrm{~mm}$ distant (Figure 8).
Geographical distribution ranges of Aloe candelabrum and Aloe ferox

Both species are confined to either southern Africa (Aloe ferox) or South Africa (Aloe candelabrum), with Aloe ferox predominating in the Western and Eastern Cape provinces of South Africa, extending northwestwards into the Free State province, as well as southern Lesotho. It does not occur in KwaZulu-Natal, and no specimens are known from the Northern Cape province, even though it occurs close by the juncture of that territory with both the Western and Eastern Cape provinces (Figure 16).

Aloe candelabrum, on the other hand, is confined to southeast-central KwaZulu-Natal, South Africa, where it is more or less restricted to the northern and western aspects of valleys of all river systems from the Mtamvuna northwards to the Mngeni. This species in its typical form is a particularly prominent component of the landscape of the Mkomazi River system, and those to the north. The entire distribution range of Aloe candelabrum falls within the Maputoland-Pondoland Region of Endemism on the eastern seaboard of South Africa (Van Wyk \& Smith, 2001). Along the actual KwaZulu-Natal coastline, Aloe candelabrum is replaced by Aloe thraskii Baker, which is also a robust, tall-stemmed species, albeit with shorter, more dense inflorescences. Within the range of $A$. ferox in the Eastern Cape, from north of Port Elizabeth to near Humansdorp, Aloe africana Mill. occupies a com- 


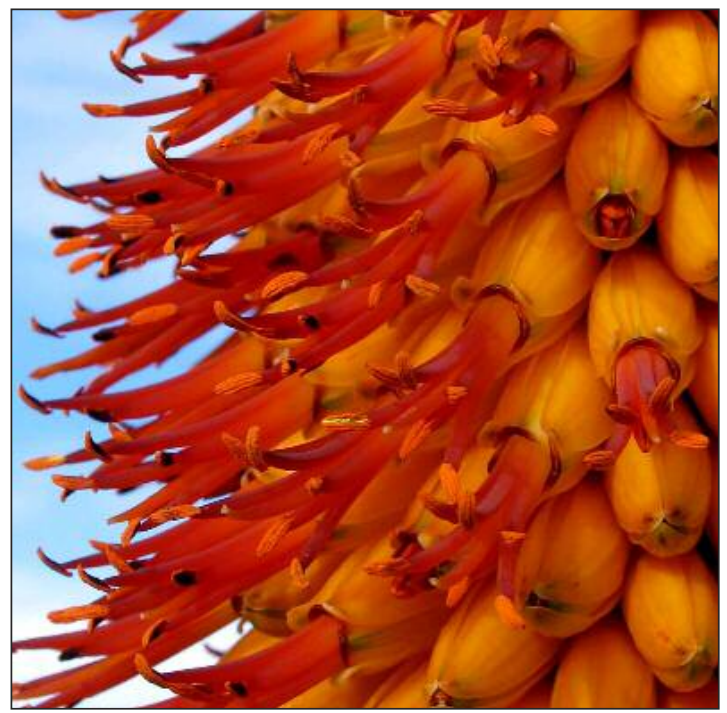

Figure 10. Bright orange flower form of Aloe ferox, also with prominent, dark inner tepal apices that typically do not flare, Jansenville, Eastern Cape province. Across its range, perianth colour varies from scarlet through orange and yellow to white. Photograph: Neil R. Crouch.

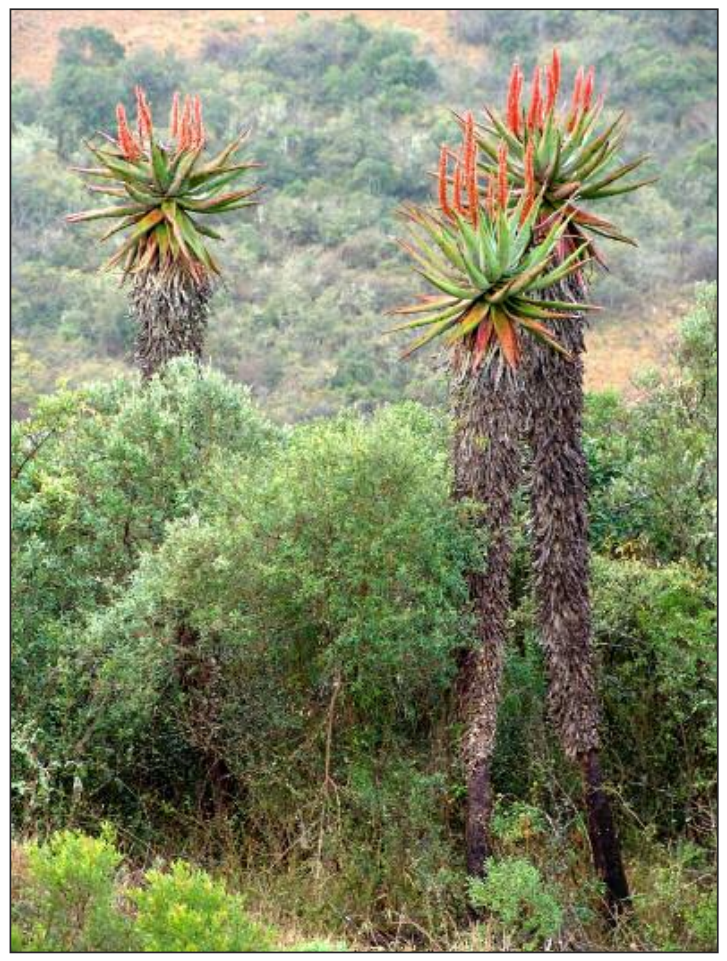

Figure 12. Tall specimens of Aloe candelabrum at Izingolweni, southern KwaZulu-Natal province. These plants share various characteristics with $A$. ferox, including erect to spreading leaf orientation. Photograph: Geoff Nichols.

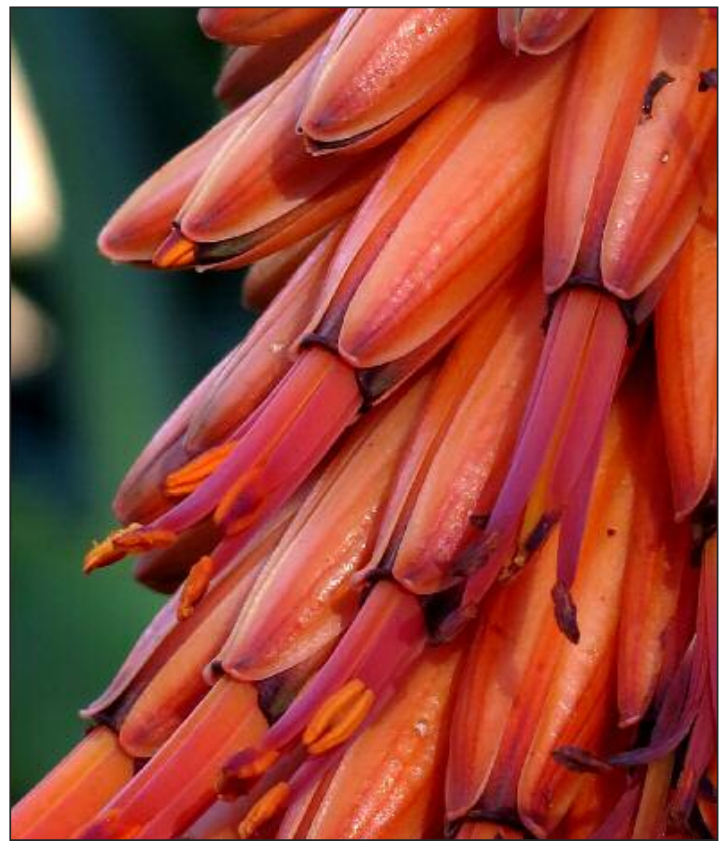

Figure 11. Reddish-orange flowers of Aloe ferox, with inner tepal apices that seemingly clasp the extended filaments, Queenstown, Eastern Cape province. The tips of the inner tepals of Aloe ferox are brown to deep brown, or at least more intensely coloured than the rest of the corolla.

Photograph: Neil R. Crouch.

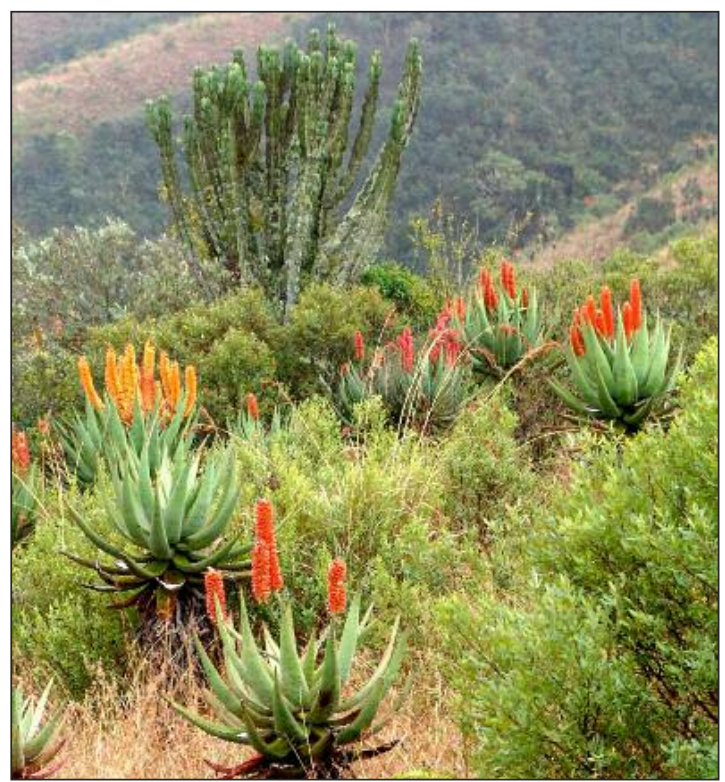

Figure 13. Colony of Aloe candelabrum, Izingolweni, southern KwaZulu-Natal. Flower colour variation is evident, as is the absence of recurved leaves.

Photograph: Geoff Nichols. 


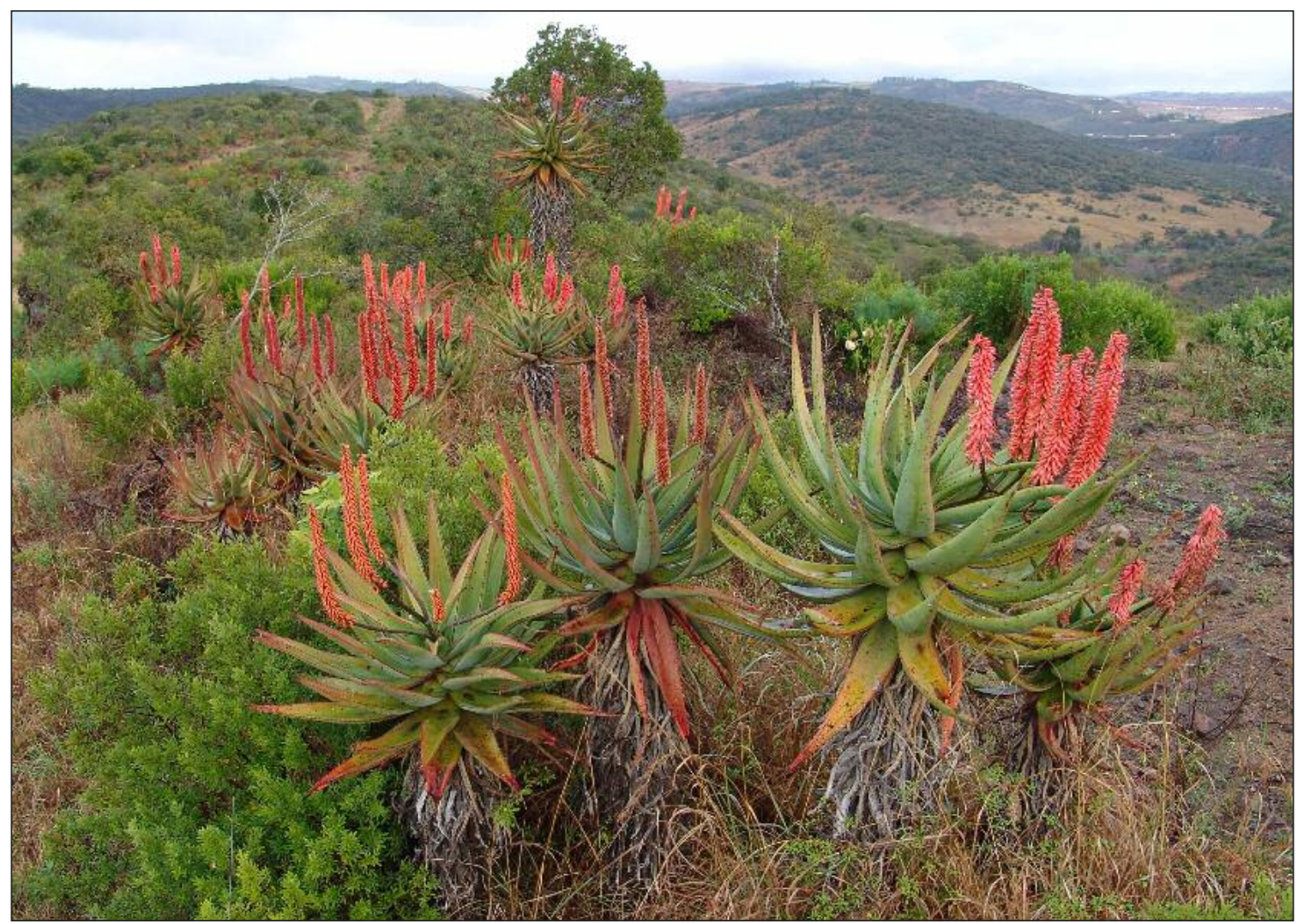

Figure 14. Some recurved leaves are shown in this group of Aloe candelabrum plants at Izingolweni, southern KwaZulu-Natal.

Photograph: Geoff Nichols.

parable niche in the littoral zone. However, unlike A. thraskii, A. africana also occurs at locations in the interior (see maps in Van Wyk \& Smith, 2014: $52[$ A. africana] and $80[$ A. thraskii] $)$.

A single specimen known to us (A.T.D. Abbott $7003[\mathrm{NH}])$ locates a tree-like aloe with white tepal tips in the extreme north of the Eastern Cape province, near Mbizana, on a ridge above the Mtamvuna River at an altitude of $640 \mathrm{~m}$. The colony from which the specimen (comprising a raceme branch only) was gathered in 1996 was recorded as a mixture of orange, red and whiteflowered plants. As the original collecting label indicates that the flowers were from a white-flowering plant, we are unable to determine whether this material represents $A$. ferox or $A$. candelabrum. Until the colony is revisited and assessed, we deem $A$. candelabrum to be documented only from KwaZulu-Natal province; it is though highly likely to occur to the immediate south in Eastern Cape province. Albinistic blooms such as those noted at Mbizana are seldom reported for A. candelabrum, but have been observed both at Izingolweni and Ashburton
(Figures 6 and 17), in the south and the northwest of its range, respectively.

\section{Taxonomy of Aloe candelabrum}

The name Aloe candelabrum A.Berger is listed as an illegitimate name (nom. illeg.) in databases such as The Plant List (http://www.theplant list.org/). This originates from a wrong entry in Index Kewensis for Aloe candelabrum Tod. in Hortus Botanicus Panormitanus: 46 (1876) that has been taken up in IPNI (http://www.ipni.org/). As both names [Aloe candelabrum Tod. (1876) and Aloe candelabrum A.Berger (1906)] are listed in IPNI, and the former is regarded as having priority, Berger's name appears to be an illegitimate later homonym (Reynolds, 1950) and has been treated as such by some authors (e.g. Govaerts, 2016). However, in Todaro (1876-1878: 66 [not page 46 as given in Index Kewensis and IPNI]) the name published is in fact Agave candelabrum Tod., which is probably a synonym of Agave cantala (Haw.) Roxb. ex Salm-Dyck (see Gentry, 1982). Aloe candelabrum A.Berger is therefore legitimate (Figueiredo \& Smith, 2012). 


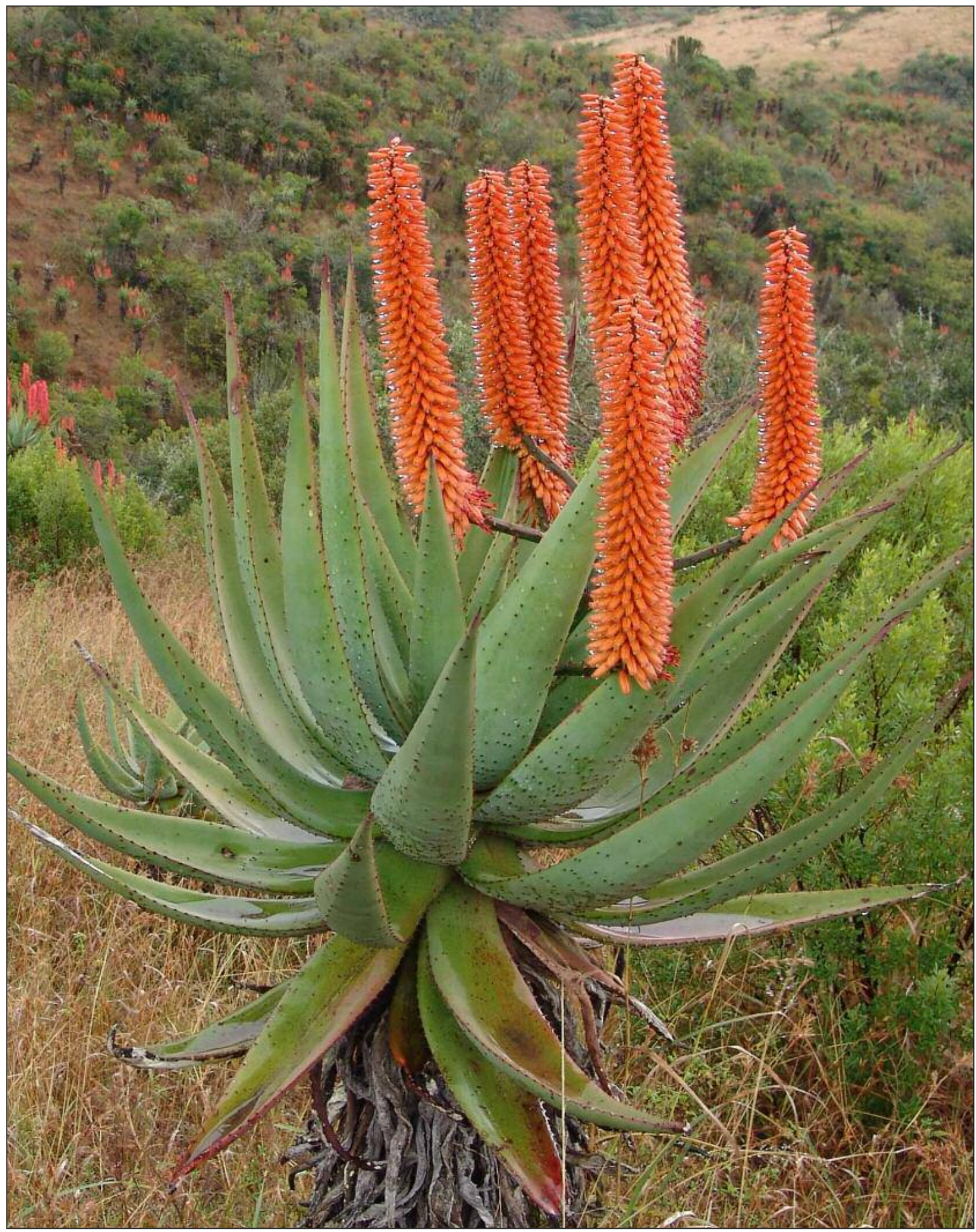

Figure 15. The arrangement of leaf prickles on this Aloe candelabrum plant at Izingolweni in southern KwaZulu-Natal is comparable to that observed in some Aloe ferox specimens from the Eastern Cape province. Photograph: Geoff Nichols. 


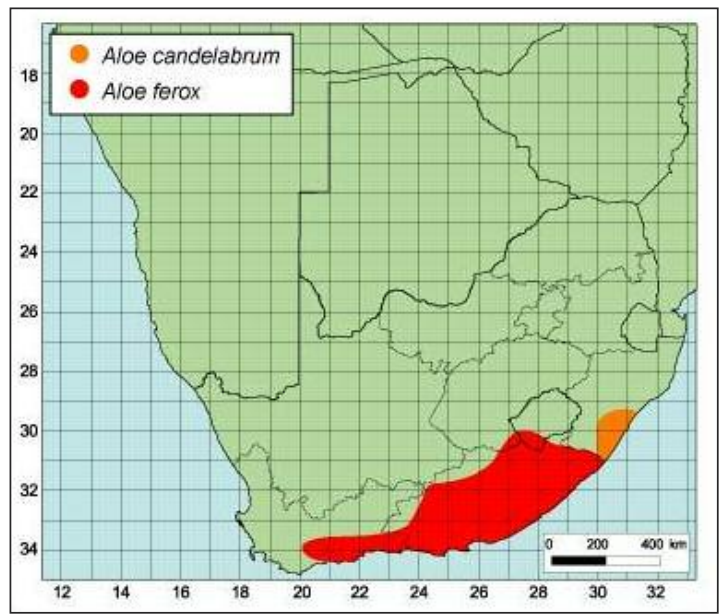

Figure 16. Known geographical distribution range of Aloe candelabrum (orange shading) and Aloe ferox (red shading) in southern Africa (South Africa and Lesotho).

Reference by Jacobsen (1986: 150) to "Aloe candelabrum Engl. \& Drude" is incorrect as these authors did not actually publish a later homonym of Aloe candelabrum A.Berger (1906: 246). Rather, Engler \& Drude (1908: 415, Fig. 353) misidentified a population of Aloe thraskii, South Africa's Dune aloe, as constituting Aloe candelabrum.

Aloe candelabrum A.Berger in Notizblatt des Königlichen Botanischen Gartens und Museums zu Berlin-Dahlem 4 (38): 246 (1906). A.Berger in Das Pflanzenreich IV. 38. III. II. Heft 33: 306 (1908); Dyer in The Flowering Plants of South Africa 24: t. 945 (1944); Groenewald, Die aalwyne van Suid-Afrika, Suidwes-Afrika, Portugees OosAfrika, Swaziland, Basoetoeland, en 'n spesiale ondersoek van die klassifikasie, chromosome en areale van die Aloe Maculatae: 66 (1941); Reynolds, The aloes of South Africa: 468-470 (1950); Jeppe, South African aloes: 39 and plate on following page (1969); Jacobsen, Lexicon of succulent plants. Short descriptions, habitats and synonymy of succulent plants other than Cactaceae: 74 (1970); Bornman \& Hardy, Aloes of the South African veld: 260-261 (1971); Jacobsen, A handbook of succulent plants, vol. 1: 149-150 (1986); Smith \& Van Wyk, Aloes in southern Africa: 86 (2008); Grace et al., The aloe names book: 30 (2011). Type: [South Africa] Flora of Natal, N [Natal] Botanic Gardens, July 1890, J. Medley Wood 4345 (B†, holo-; US US00680243!, iso-).

Note: The holotype is not extant at B and was probably destroyed in 1943, during WWII (R. Vogt, pers. comm. on 28 July 2016).

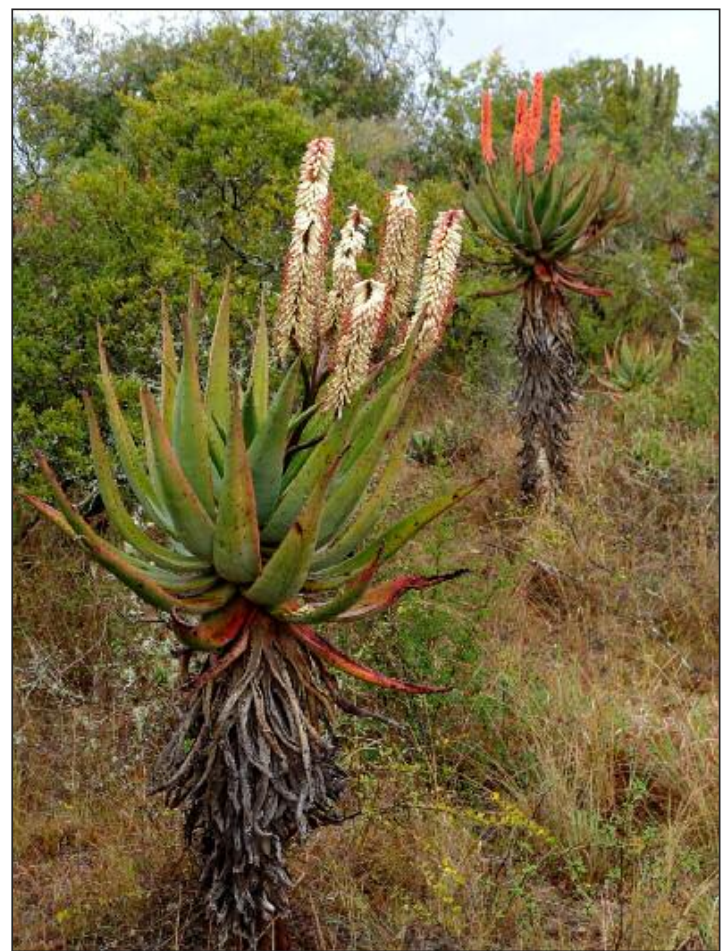

Figure 17. A white-flowering plant of Aloe candelabrum at Izingolweni in southern KwaZuluNatal.

Photograph: Geoff Nichols.

\section{Description}

Solitary, arborescent plant up to $2-4 \mathrm{~m}$ high. Stem simple, erect, 2-4(-8)m high, densely covered with persistent, down-curved, dried leaves. Leaves densely rosulate, spreading to recurved, dull green to glaucous, without spots, surfaces smooth, lanceolate-ensiform, $\pm 100 \mathrm{~cm}$ long, $15 \mathrm{~cm}$ wide at base, lower surface with few spines in median line near apex, occasionally with few scattered spines; margin reddish, cartilaginous, with pungent, reddish to brownish red, deltoid teeth, \pm $3 \mathrm{~mm}$ long, $15-20 \mathrm{~mm}$ apart; exudate honey coloured. Inflorescence usually single, $\pm 1 \mathrm{~m}$ high, erect, 5- to 12-branched from below middle, branches erect. Peduncle stout, somewhat sulcate, compressed low down; with several sterile bracts below racemes. Racemes cylindric, slightly acuminate, $50-80 \mathrm{~cm}$ long, $\pm 10 \mathrm{~cm}$ wide, terminal raceme often the longest, presenting higher than lateral racemes, very dense; buds horizontal, flowers horizontal or nodding when open. Floral bracts ovate-deltoid, $\pm 10 \mathrm{~mm}$ long, $\pm 5 \mathrm{~mm}$ wide, white, thin, scarious, 5- to 7-nerved. Pedicels $6 \mathrm{~mm}$ long. Flowers: perianth scarlet, sometimes rose-pink or orange, with white or pale segment tips, $\pm 32 \mathrm{~mm}$ long, $\pm 5 \mathrm{~mm}$ across ovary, widening above ovary to $\pm 8 \mathrm{~mm}$ towards slightly upturned mouth, 
clavate-cylindric, slightly ventricose; outer segments free for $16-22 \mathrm{~mm}$, tips spreading to slightly flared; stamens with filiform-flattened filaments, included part lemon, exserted part deep orange to purplish, exserted $20 \mathrm{~mm}$; ovary $6 \mathrm{~mm}$ long, $3 \mathrm{~mm}$ diameter, green; style with included portion lemon, exserted portion yellow, exserted $20 \mathrm{~mm}$. Chromosome number: $2 n=14$ (Vosa, 1982).

\section{Additional specimens examined}

SOUTH AFRICA: KWAZULU-NATAL. -2830

(Dundee): Meduna, Klip River Distr. (-CB), 16

July 1915, E. Keeling \& I.B. Pole Evans 110 (K);

2831 (Nkandla): Zululand region., Heatonville

(-DB), 6 June 1945, M.G. de Waal A \& B (NH);

2929 (Underberg): Mpendhle Distr.,

Mkhomazi State Forest, $\mathrm{N}$-facing slopes of $\mathrm{Mu}-$

langane (-DB), 27 July 1985, Pitchford s.n. (K, PRE);

2930 (Pietermaritzburg): Richmond Distr., Aloe Corner (-C), 13 July 1966, E.J. Moll 3283 (K, PRE); Maritzburg (-CB), 7 April 1916, E.M. Doidge 165 (K; PRE); Pietermaritzburg, Otto's Bluff (-CB), August 1943, F.Z. van der Merwe 2666 (PRE); Inchanga, between Durban and Pietermaritzburg (-DA), 2 June 1935, G.W. Reynolds 1397 (PRE); Inchanga, about 25 miles west of Durban (-DA), May 1954, L.C. Leach 101 (PRE); Ndwedwe, 3 miles west of Ndwedwe (-DB), 13 July 1966, E.J. Moll 3287B, C, D (PRE); Mariannhill (-DD), July 1916, H.W.R. Marloth 7339 (PRE);

2931 (Stanger): Msundusi, Coll. Foxen's farm (-CA), 2 August 1928, J.W. Bews 255 (PRE);

3029 (Kokstad): Harding District (-DB), 3 July 1953, J. Gibbs s.n. (K);

3030 (Port Shepstone): Ixopo (-AA), June 1936, G.G. Smith 150 (PRE); Alexandra County, Friedenau, Umgaye Flats (-AD), 24 July 1910, H.H. Rudatis 809 (PRE); Port Shepstone, Horseshoe Farm (-CA), 5 August 1965, R.G. Strey 5876 (NH, PRE); Umtamvuna, Gundrift, Mpunzi bridge (-CC), 14 June 1969, R.G. Strey 8704 (NH, PRE); Umtamvuna Nature Reserve, Protea Point (-CC), 25 June 1987, A. Abbott 3947 (NH, PCE).

Common names: See Grace et al. (2011: 30) for a comprehensive list.

Flowering time: Mid-winter (June-July; Southern Hemisphere).

\section{Acknowledgements}

We are grateful to Dr Robert Vogt, Herbarium Curator (B), Botanischer Garten und Botanisches Museum Berlin-Dahlem, Freie Universität Berlin, Berlin, Germany, for checking the collection for type material of Aloe candelabrum. Geoff Nichols generously allowed reproduction of his excellent photographs, and Ben Botha access to cultivated material; both kindly shared their field experiences and observations. Dr Graham Grieve is thanked for commenting on a locality in the Mtamvuna River system.

Anonymous referees are thanked for their comments on the manuscript.

\section{References}

BERGER, A. (1906). III. Neue Aloineen und andere Sukkulenten. Notizblatt des Königlichen Botanischen Gartens und Museums zu BerlinDahlem 4(38): 246-249.

Berger, A. (1908). 8. Aloe L. In: A. Engler (ED.), Liliaceae-Asphodeloideae-Aloineae. Das Pflanzenreich IV. 38. III. II. Heft 33, pp. 159326. Verlag von Wilhelm Engelmann: Leipzig.

BornMan, H. \& HARDY, D. [S.] (1971). Aloes of the South African veld. Voortrekkerpers, Johannesburg.

Dyer, R.A. (1944). Aloe candelabrum. The Flowering Plants of South Africa 24: t. 945.

Engler, A. \& Drude, O. (1908). Die Vegetation der Erde. Sammlung Pflanzengeographischer Monographien. IX. Die Pflanzenwelt Afrikas insbesondere seiner tropischen Gebiete. Grundzüge der Pflanzenverbreitung in Afrika und die Characterpflanzen Afrikas. II. Band. Verlag von Wilhelm Engelmann, Leipzig.

Figueiredo, E. \& SMith, G.F. (2012). Clarifying the application of the long-confused name Aloe commutata, and the establishment of Aloe $\times$ commutata Tod. (Asphodelaceae). Bradleya 30: 25-32.

Gentry, H.S. (1982). Agaves of continental North America. The University of Arizona Press, Tucson.

GLeN, H.F. \& HARDY, D.S. (2000). Aloaceae (First part): Aloe. In: G. GERMishUIZEN (ED.), Flora of southern Africa Vol. 5, Part 1, Fascicle 1: 1167. National Botanical Institute, South Africa.

GOVAERTS, R. (2016). World checklist of Xanthorrhoeaceae: Aloe. Facilitated by the Board of Trustees of the Royal Botanic Gardens, Kew. Available online at http://apps.kew.org/wcsp/. Accessed July 2016. 
Grace, O., Klopper, R.R., Figueiredo, E. \& Smith, G.F. (2011). The aloe names book. Strelitzia 29. South African National Biodiversity Institute, Pretoria, and Royal Botanic Gardens, Kew.

Groenewald, B.H. (1941). Die aalwyne van SuidAfrika, Suidwes-Afrika, Portugees Oos-Afrika, Swaziland, Basoetoeland, en 'n spesiale ondersoek van die klassifikasie, chromosome en areale van die Aloe Maculatae. Die Nasionale Pers Beperk, Bloemfontein.

JACOBSEN, H. (1970). Lexicon of succulent plants. Short descriptions, habitats and synonymy of succulent plants other than Cactaceae. 2nd edn. Blandford Press Ltd, Poole, Dorset.

JACOBSEN, H. (1986). A handbook of succulent plants. Vol. 1. Abromeitiella to Euphorbia. Blandford Press Ltd, Poole, Dorset.

Jeppe, B. (1969). South African aloes. Purnell \& Sons S.A. (Pty) Ltd, Cape Town.

KLOPper, R.R. \& SMith, G.F. (2010). Notes on African plants. Asphodelaceae: Alooideae. Reinstatement of Aloe spectabilis. Bothalia 40: 91-93.

REYnolds, G.W. (1950). The aloes of South Africa. The Aloes of South Africa Book Fund, Johannesburg.

Smith, G.F., Figueiredo, E., Klopper, R.R. \& Crouch, N.R. (2012). Summer-flowering species of maculate Aloe L. (Asphodelaceae: Alooideae) in the Aloe zebrina-complex from South Africa: reinstatement of four names, and description of $A$. braamvanwykii Gideon F.Sm. \& Figueiredo. Bradleya 30: 155-166.
SMith, G.F. \& VAN WyK, A.E. [BRAAM]. (2008). Aloes in southern Africa. Struik Nature (an imprint of Random House Struik (Pty) Ltd), Cape Town.

Todaro, A. (1876-1878). Hortus Botanicus Panormitanus, 1. Cyri Visconti \& Francisci Lao, Palermo.

VAN WyK, A.E. [BRAAM] \& SMith, G.F. (2001). Regions of floristic endemism in southern Africa. $A$ review with emphasis on succulents. Umdaus Press, Hatfield, Pretoria.

VAN WyK, B-E. [BEN-ERIK] \& SMITH, G.F. (2014). Guide to the aloes of South Africa. 3rd edition. Briza Publications, Queenswood, Pretoria.

Viljoen, A.V., Van WyK, B-E., VAn Der Bank, H., SMith, G.F. \& VAN DER BANK, M. (1996). A chemotaxonomic and biochemical evaluation of the identity of Aloe candelabrum (Aloaceae). Taxon 45: 461-471.

VosA, C.G. (1982). Chromosome studies in the southern African flora: 30-37 Aloe spp. Journal of South African Botany 48: 409-424. 